JOURNAL OF BUSINESS

MANAGEMENT AND ACCOUNTING

http://e-journal.uum.edu.my/index.php/jbma

How to cite this article:

Md Nor M. Z., Mohamad, A. M., Mohd Arshad, A. H. \& Abdul Jalil, N. I. (2021). Rent to own as value-based financial intermediation: Legal and shariah analysis. Journal of Business Management and Accounting, 11(1), 45-58. https://doi.org/10.32890/ jbma2021.11.1.3

\title{
RENT TO OWN AS VALUE-BASED FINANCIAL INTERMEDIATION: LEGAL AND SHARIAH ANALYSIS ${ }^{1}$
}

\author{
${ }^{1}$ Mohd Zakhiri Md Nor, ${ }^{2}$ Ani Munirah Mohamad, \\ ${ }^{36}$ Ain Husna Mohd Arshad \& ${ }^{4}$ Najah Inani Abdul Jalil \\ 1, 2,3,4 School of Law, Universiti Utara Malaysia, Malaysia
}

${ }^{1}$ Corresponding Author: zakhiri@uum.edu.my

Received: 16/4/2020 Revised: 17/9/2020 Accepted: 22/9/2020 Published:31/1/2021

\begin{abstract}
Generally, Rent to Own (RTO) is a financial scheme offered by financial institutions to help those who cannot afford the $10 \%$ initial deposit and access to financial schemes. One value-based intermediation (VBI) initiative is the RTO Islamic financing product. The market segment of this product is for the new generation whereby they can own a house without paying any deposit on account of the fact that housing estates are increasingly expensive. This paper starts with the background concept of VBI, then it discusses on the modus operandi of RTO offered by financial institutions. This paper

1 This article is an extended version of a paper titled "The application of the principle of ijarah muntahiah bi al-tamlik as a value-based intermediation on rent to own financing product", presented at International Case Study Conference, 24-26 November 2019, Kota Kinabalu, Sabah.
\end{abstract}


also discusses legal and Shariah aspects related to RTO. Adopting a qualitative method, the data were collected through semi-structured interviews with relevant parties involved with the RTO product. In addition, some preliminary information had been accessed through the financial institution's website. This paper found that RTO has played important roles as one viable VBI initiative and it is approved as a Shariah compliant product.

Keywords: Value-based intermediation, rent to own, legal, Shariah

\section{INTRODUCTION}

Value-based intermediation (VBI) aims to deliver the intended outcomes of Shariah through practices, conduct, and offerings that generate positive and sustainable impact on the economy, community and environment, which is consistent with the shareholders' sustainable returns and long-term interests (BNM, 2018b). This concept was officially introduced on 3 August 2018. One initiative under VBI is a new financial scheme for housing, which is known as Rent to Own (RTO) as introduced by Islamic financial institutions, such as Maybank and other participating institutions. This study focused on RTO product issued by an Islamic financial institution as one VBI initiative. The purpose of this product is to help customers that faced difficulties in paying the down payment for the purchase of their house. However, it seems that the problem with this product is lack of financing accessibility to B40 group to own the house, clarity of Islamic leasing contract used and its Shariah objectives (Maqasid Shariah), the excessive rental rate, and the clarity of legal issues and legal documentation involved.

\section{OVERVIEW OF THE CONCEPT OF VALUE-BASED INTERMEDIATION (VBI)}

The objective of VBI is to generate positive and sustainable impact to the economy, community, and environment through practices, processes, offerings, and conduct. Bank Negara Malaysia (BNM, 2018a) issued three documents to facilitate the implementation of VBI inter alia the implementation guide for VBI, the VBI financing and investment impact assessment framework, and the VBI scorecard. 
The assessment framework provides guidance on the assessment of financing and investment applications, taking into consideration the economic, social, and environmental impacts, while the scorecard supports the implementation of performance measurement framework for Islamic financial institutions that drive positive value and impact on society and the environment (Yunus, 2018).

VBI can benefit the financial industry in terms of innovation, enhanced efficiency, and a more effective ecosystem. For the customer and community, it will improve standard of living via fair and transparent treatment. VBI also helps the government to realign business focus with national agenda, and for regulators, it will strengthen financial stability (BNM, 2018b). According to Roshayani, Ruhaini, Ramesh, and Idora (2018), a study conducted on the growth rate of Islamic banks indicated that the Islamic financial industry needs to adjust its focus beyond Shariah-compliance toward more wholesome value creation and value-based activities in ensuring long-term sustainable growth.

VBI will boost Islamic finance to a higher level, which is backed with Shariah principles and values. VBI also encourages Islamic financial institutions to go beyond banking and encourages good and ethical behaviour. This study focused on Rent to Own (RTO) product issued by one Islamic bank as one of the VBI initiatives. The purpose of this product is to help customers that cannot provide down payment to purchase their own home. In a study conducted by Ebekozien, AbdulAziz, and Jaafar (2019), inability to make down payment has been identified as one of the root causes of housing finance inaccessibility by low-income earners in Malaysia. Therefore, this initiative seems to address the national issue of house affordability.

\section{RENT TO OWN (RTO) AS VALUE-BASED INTERMEDIATION}

The Government allocated RM10 billion for RTO financing scheme in the 2020's budget and this will be applied to purchase of first homes, with the property value of up to RM 500,000.00 (New Straits Times, 2020). In RTO, the lessee can rent a house from the bank for up to five years. After one year, the lessee has the option of whether to buy the 
house at the price fixed during tenancy period or to sell it to a third party to get capital gain (Hasnor, personal communication, November $15,2019)$.

\section{Modus Operandi and Process Flow of RTO}

This financing product gives the option to the buyer or tenant to buy the asset at the end of rental period. The financial institution is partnered with several housing developers. By virtue of Section 28 of IFSA 2013, it is the duty of the bank as to ensure that the entire operation of the banks are Shariah compliance. The bank also could specify Shariah standards by virtue of Section 29 of IFSA 2013. Article 13.3 of Ijarah Shariah Standard of BNM allows Islamic banks to own the asset (BNM, 2018c). By using RTO, the bank is the owner of the house (lessor) and after that they rent it to the customer (lessee).

The salient features of RTO are that there will be flat rental rate for the first five years of rental tenure, $100 \%$ stamp duty exemption for Sale and Purchase Agreement, option for seamless transition into mortgage after minimum of 12 months renting, and there will be $2 \%$ annual rent hike after entering the $6^{\text {th }}$ year (Maybank2u, 2020).

In terms of the eligibility, the customer of the bank shall be a Malaysian citizen or Permanent resident in Malaysia, with the minimum household combined gross income of RM5,000.00. The applicants can bring up 3 guarantors and they must be from family members. The applicant and guarantors must not have more than one house at the time the application is made (Maybank2u, 2020).

In this regard, the buyer or tenant contracting RTO would not need to pay $10 \%$ down payment and can lock the unit at the predetermined price. Directly or indirectly, this could help the developer to clear the unsold property. During the tenancy period, the developer somehow or rather will lose control over the property. The developer also has to bear all maintenance costs in the event that the buyer or tenant refuses to buy the property (Nor, Mohamad, Arshad \& Jalil, 2019).

\section{Ijarah as the Underlying Contract of RTO}

Ijarah is permissible according to Islamic jurist and it is a sale of usufruct (Al-Zuhayli, 2003). RTO closes to the contract of ijarah 
muntahiah bi al-tamlik (rent and to own property at the expiry of rental period) (Nor et al., 2019). There are various types of ijarah muntahiah bi al-tamlik (Lahsasna, 2010) inter alia:

i) Ijarah muntahiah bi al-tamlik through transfer of legal title (sale at the end of lease period for token consideration) in which, if the ijarah period expires, then the ijarah period would be nullified and there is a promise to enter a sale to be concluded at the end of ijarah period, if the lessee wishes so and has paid the agreed consideration.

ii) Ijarah muntahiah bi al-tamlik through transfer of legal title (sale at the end of lease period from amount specified in the lease).

iii) Ijarah muntahiah bi al-tamlik through transfer of legal title (sale) prior to end of lease term for a price equivalent to remaining ijarah instalments.

iv) Ijarah muntahiah bi al-tamlik through gradual transfer of legal title of leased asset.

Nevertheless, in one of the interviews conducted, the respondent was in favour of the opinion that the rental payment during the rental period of RTO is actually pure ijarah because at the end of the rental tenure, the lessee has the right of option whether to buy or not of the said property (Abdul Khir, personal communication, February 11, 2020).

This study found that there is a separated agreement between financial lease agreement, and sale and purchase agreement. Therefore, the authors agreed that the underlying contract of RTO is pure ijarah whereby the lessee will enter the rental agreement with the bank for a minimum period of two years with the maximum of five years, and later on, the lessee can enter into sale and purchase agreement either with the contract of bay bithaman ajil, tawarruq, or the like.

\section{LEGAL ASPECTS OF RTO}

The following are some legal issues arising out of the RTO contract and the data collected though semi-structured interviews with a banker and Shariah scholar. The questions for the semi-structured interview were tested via a pilot test and examined by academicians 
who are experts in this area of research. This paper highlights some legal aspects of RTO, as described in the following sections.

\section{Ownership of the House}

During the rental period, the ownership of the house belongs to the bank. By virtue of Section 29.1 of Financial Services Act 2013 and S.13.3 of Ijarah Policy document issued by BNM, the bank can own the property (BNM, 2018d). In the case of RTO, the developer sells the house to the bank and the latter rents to the customer for a minimum period of two years and maximum of five years. During this rental period, the ownership of the house belongs to the bank. The relationship between the bank and customer under RTO is lessor and lessee, respectively, while the applied underlying contract is ijarah. It is viewed and must be emphasised that industry players also need to comply with Shariah parameters on ijarah as issued by BNM. It is different with other housing financing facilities in the sense that the customer of the bank will enter into sale and purchase agreement and thereto the customer has the ownership of the house.

\section{Mortgage Reducing Term Insurance}

During the rental period of RTO, the lessee will not be covered with Mortgage Reducing Term (MRT) Insurance. MRT will be covered upon the customer's signing of the Sale and Purchase Agreement (SPA) with the bank when they make the option to buy the house as registered owners (Hasnor, personal communication, November 15, 2019). This will trigger legal issues whereby the lessee would not be covered under MRT during RTO period.

\section{Nominee Issues}

In event of the death of lessee during the rental period, the nominee will continue with the arrangement (Hasnor, personal communication, November 15, 2019). In this case, the nominee will pay rent to the bank until the period of rental end. The nominee has borne the legal obligation to pay rent to the bank.

\section{Death or Total Disability}

In event of the death of lessee during the rental period of RTO financing, the lessee/customer of the bank shall be given six (6) months 
moratorium (payment relief) (Hasnor, personal communication, November 15, 2019). However, the RTO asset in this situation is not subjected to Islamic distribution of asset (faraid) since the lessee does not have full ownership of the house or property, as yet, during the rental period.

\section{Event of Default}

In the event of default by the lessee, the guarantors need to pay the rental payment (Hasnor, personal communication, November 15, 2019).

\section{Employee Provident Fund (EPF)}

Customers are not allowed to withdraw money from their EPF account to pay the rental amount during the rental period because EPF requires a sale and purchase agreement (Hasnor, personal communication, November 15, 2019). The situation is not the same in a normal sale and purchase agreement whereby the customer is eligible to withdraw from his or her EPF account to pay the $10 \%$ deposit as part of the selling price of the property.

\section{Major Maintenance and Repair}

With regard to major maintenance and repair, the customer needs to comply with the finance lease agreement (Hasnor, personal communication, November 15, 2019). Major maintenance and repair are needed to retain the building and return it to an acceptable condition to the extent that the building functions as intended.

\section{Force Majeure}

Force majeure refers to events that could possibly affect the contract or cause contractual non-performance that is beyond the control of contracting parties, such as natural disaster, death of lessee, and et cetera (Law \& Martin, 2014). In the case of a force majeure event, the takaful will cover (Hasnor, personal communication, November $15,2019)$.

\section{Tax Exemption}

With regard to stamping of Memorandum of Transfer (MOT), there is a circular issued by Inland Revenue Board to consider one transaction 
during the rental period, and sale and purchase period. Real Property Gain Tax (RPGT) will be calculated from the rental period (Hasnor, personal communication, November 15, 2019). However, the National House Buyer Association argued that this exemption cannot be applied to houses valued at above RM 500,000 because it does not meet the meaning of affordable house by Housing Ministry (Daily Express Property, 2019).

\section{Hibah}

Hibah does not take effect during the rental period because the lessee does not have full ownership of the house as yet (Hasnor, personal communication, November 15, 2019; Abdul Khir, personal communication, February 11, 2020). Under Islamic law of hibah, the one that wants to give hibah should have full ownership right of the property.

\section{Challenges at the Conveyancing Stage}

There is a mismatch between customer expectation with the industry offer or real situation. For this issue, it is viewed that the customer needs to be educated on the process and flow of RTO (Hasnor, personal communication, November 15, 2019). The customer needs to understand that they do not have the ownership right over the property as yet during the rental period of RTO. Based on Rent to Own Product Disclosure Sheet dated October 2018, the process flow of RTO begins with the customer having to choose a property from the portal. The customer needs to upload all the necessary documents to www.maybank2own.com and check their eligibility. Once approved, the customer should choose a property in the portal or other property that he or she intends to own. Upon successful application,

i) the customer is required to execute the Lease Agreement, Guarantee Agreement (if applicable), and pay security deposit and all other miscellaneous charges (if any).

ii) the customer is required to open a Maybank current/savings account if he or she does not have an existing Maybank current/ savings account for debiting payment.

iii) the bank shall have the sole right to determine whether the conditions precedent $(\mathrm{CP})^{*}$ are met, failing which the bank is entitled to terminate the Lease Agreement within three months 
from the Lease Agreement date. The security deposit will be refunded to the applicant.

iv) the applicant needs to furnish any necessary documents requested by the bank within 14 days from the date of receiving a written request from the bank.

During the rental tenure, the applicant is required to,

i) promptly pay the monthly rental payment due on 22nd day of each calendar month via standing instruction;

ii) promptly pay all expenses and charges with respect to property such as taxes, takaful, quit rent, maintenance fees, utilities, and etc.; liaise directly with the developer in case of any defects to the property;

iii) for cases of direct purchase from seller, the applicant will receive the Property in as is condition; and

iv) ensure the property is maintained in a clean, good and tenantable condition, at a standard acceptable to the bank at all times and inform the bank on any rectification and remedial work done to the property to address defects or damages.

The following options are available during the rental period.

i) Customers are able to opt to own after 12 months at the corresponding price in the purchase price schedule, as indicated in the lease agreement.

ii) Customer options after 12 months of renting are,

a) own the home,

b) sell the home and keep $100 \%$ profit (nett gain from sale proceeds), and

c) continue renting until end of tenure and get the property at RM1.

iii) Exit without further obligation after a five-year rental period. Security deposit will be refunded nett of all remaining outstanding due to the bank, upon exercising any of the options.

In the event the applicant terminates within the five-year lock-in period, the applicant will be liable to repay the remainder of the rental period. Should the bank is able to find a new customer to undertake a lease for the said property, the rental due by the existing customer for the remaining period will be waived (should they have paid up, it will be refunded to them). 


\section{Maturity of Rental Tenure}

The applicant will enjoy the ownership of the property from the bank upon maturity of rental tenure at RM1, subject to the following.

i) There is no amount outstanding or due from the applicant to the bank.

ii) The applicant has made the final rental payment for final month of the last rental tenure period as stated in the Lease Agreement.

iii) There is no event of default having occurred and subsisting.

iv) The applicant has delivered all the necessary documents for completion of obtaining State Authority's consent to transfer (if applicable).

\section{SHARIAH ASPECTS OF RTO}

Though this product is already endorsed by Shariah committee of Islamic financial institution and approved by BNM, it seems that there are some Shariah issues arising out of the contract of RTO, which are described in the following sections.

\section{Affordable House and Maqasid Shariah}

The underlying Shariah contract for RTO is ijarah (Maybank Islamic, 2017). The product should be in-line with Maqasid Shariah and address the issues of affordable housing. Under the ijarah principle, a contract can take effect at a future date on the condition that rent will be payable only after the asset for lease is delivered. The rent should be charged after the lessee has taken delivery of the asset, and not from the day the price has been paid. Therefore, the commencement date for RTO should be on the day vacant possession is actually delivered. This practice is basically in line with Shariah principle. The RTO should be offered to the house below RM 300,000 so that it is in-line with the definition of affordable housing in Malaysia.

\section{Rental Payment}

Under the RTO, the buyer or tenant should promptly pay monthly rental payment due on the 22nd of each calendar month via standing instruction. A question is raised here as to whether the monthly rental 
amount is pure rental during the rental period or there is an element of profit to the bank. This will trigger Shariah issues and the bank should not earn that profit during the rental period of RTO.

\section{Maintenance of the Property}

Under the RTO, the terms and condition of maintenance of property are as follows.

i) Promptly pay all expenses and charges with respect to the property such as taxes, takaful, quit rent, maintenance fees, and utilities.

ii) Lease directly to the developer in case of any defect to property.

iii) For cases involving direct purchase from seller, the applicant will receive the property in an as-is condition.

iv) Ensure the property is maintained in a clean, good, and tenable condition, at a standard acceptable to the bank at all times, and inform the bank of any rectification and remedial work done to the property to address defects or damages.

Under Shariah law, major maintenance should be borne by the bank. However, major maintenance issues will be based on rental agreement between the lessee and the bank. The rental agreement should be based on Ijarah Policy document issued by BNM (2018a).

\section{Revocation of RTO}

Under RTO arrangement, the customer can exercise his or her right of option whereby the customer is able to opt to own after 12 months at the corresponding price in the purchase price schedule as indicated in the lease agreement. The customer can opt after two months of renting to own the home. The customer also has the option to sell the home and keep $100 \%$ profit. In addition, the contract also gives the right to the customer to exit without further obligation after a five-year rental period, and security deposit will be refunded nett with all remaining outstanding due to the bank, upon exercising any of the options.

A question arises as to what the position is if the customer opts to exit before the 12 months. Does the customer still need to pay the total amount of rental period? Will it trigger any Shariah issues? This study found that the customer needs to pay the entire five-year rental period if the lessee decides to exit after two years from the establishment of 
rental agreement. The bank is allowed to collect such rent because the bank would not allow other lessees to rent the house. In this event, the lessee, the nominee, or the guarantor still has to pay the rental amount due.

\section{Shariah Compliant RTO Product}

There are various lines of defence and layers to ensure the RTO is a Shariah compliant product. Basically, this product has been endorsed by Shariah Committee and approved by the Central Bank of Malaysia. The practice of RTO is generally in line with the principle of ijarah muntahiah bi al-tamlik which specifically is ijarah muntahiah bi altamlik through transfer of legal title (sale at the end of lease period for an amount specified in the lease). Though RTO is a Shariah compliant product, there are issues that need to be explored with regard to who should bare the rental and maintenance of the house during the transition of rental and sale agreement. In addition, an issue is whether the lessee should pay the remaining rental amount if he or she decides to exit less than two years into the rental agreement, and without the intention to buy the house or enter the contract of sale. It is because under ijarah contract either lessor or lessee can give notice to terminate the ijarah contract. Furthermore, ijarah contract is the benefit of the usufruct of the property under Islamic law.

\section{CONCLUSION}

RTO is a Shariah compliant product under the principle of ijarah muntahiah bi al-tamlik and it is approved by both Shariah committee of the bank and BNM. The product is very unique and regarded as one VBI product available in the market. It is simply because it is offered with a specific objective and purpose, that is, to assist the B40 group as well as those who cannot afford to pay the down payment in order to have an asset while adhering with the Maqasid Shariah. However, there are rooms to strengthen the viability of this product.

\section{ACKNOWLEDGMENT}

This paper is fully funded by Institute of Management and Business (IMBRE) under Case Study Grant, titled "Reviving Value Based 
Practices in Islamic Bank: An Appraisal" (s/o code: 14418). The authors also would like to thank all respondents and all parties involved directly or indirectly with this research.

\section{REFERENCES}

Al-Zuhayli, W. (2003). Financial transactions in Islamic Jurisprudence (4th ed.). Damascus: Dar al Fikr Mouaser.

BNM (2018a, Oct 3). Value-based intermediation scorecard, consultative document. Retrieved from https://www.bnm.gov. my/index.php?tpl=2016_search_result\&cx $=00961871858$ 2741626374\%3Aqt1v0lvdsbg\&cof=FORID\%3A11\&q=VBI.

BNM (2018b, March 12). Value based intermediation: Strengthening the roles and impact of Islamic finance. Retrieved from https://www.bnm.gov.my/index.php? ch=57\&pg=137 $\& a c=612 \& b b=$ file.

BNM (2018c, June 12). Ijarah. Retrieved from https://www.bnm.gov. my/index.php?ch=57\&p g=137\&ac=530\&bb=file.

BNM (2018d). Ijarah policy. Retrieved from https://www.bnm.gov. my/index.php?ch=57\&pg $=137 \& \mathrm{ac}=530 \& \mathrm{bb}=$ file.

Daily Express Property (Nov 4, 2019). Spotlight on rent-to-own scheme, RPGT. Retrieved from http://www.dailyexpress.com. my/interest/283/spotlight-on-rent-to-own-scheme-rpgt/.

Ebekozien, A., Abdul-Aziz, A.-R., \& Jaafar, M. (2019). Housing finance inaccessibility for low-income earners in Malaysia: Factors and solutions. Habitat International, 87, 27-35.

Lahsasna, A. (2010). SH 1003: Shariah rules in financial transactions. Kuala Lumpur, Malaysia: INCEIF.

Law, J., \& Martin E. A. (2014). A dictionary of law (7th ed.). Oxford University: Oxford University Press.

Maybank2u (2020, March). HouzKEY homeownership plan. Retrieved from https://www.mayb ank2u.com.my/maybank2u/malaysia/ en/personal/loans/home/houzkey.page.

Maybank Islamic (2017, 23 November). Maybank Islamic launches HouzKEY, Malaysia's first bank-initiated rent to own product. https://www.maybank2u.com.my/iwov-resources/islamicmy/document/my/en/islamic/about-us/news-highlights/ HouzKEY02 18 PR.PDF.

Nor, M. Z. M., Mohamad, A. M., Arshad, A. H. M., \& Jalil, N. I. A. (2019). The application of the principle of ijarah muntahiah 
bi al-tamlik as a value based intermediation on rent to own financing product. Proceedings of the International Case Study Conference, 24-26 November 2019, Kota Kinabalu, Sabah.

New Straits Times, (Oct 11,2020). 2020 Budget: RM10b allocation for rent-to-own financing scheme. https://www.nst.com.my/news/ government-public-policy/2019/10/529018/20 20-budgetrm10b-allocation-rent-own-financing-scheme.

Roshayani, A., Ruhaini, M., Ramesh, N., \& Idora, B. (2018). Valuebased intermediation for Islamic banking institutions directed towards sustainable development goals. The International Revue of Entrepreneurial Finance, 1(1).

Yunus, N. S. M. (2018). Value based intermediation-beyond profit. Retrieved from https://www.bis.org/review/r181003e.htm

\section{Interview}

Abdul Khir, M. F. (2020, February 11). Personal interview with Shariah Committee of Maybank Islamic.

Hasnor, S. M. (2019, November 15). Personal interview with Credit and Operations Manager of Maybank.

\section{Statute}

Islamic Financial Services Act 2013 